\title{
IGF-I and IGF-I-binding proteins in rats with adjuvant-induced arthritis given recombinant human growth hormone
}

\author{
I Ibañez de Cáceres ${ }^{1}$, M A Villanúa ${ }^{1}$, L Soto ${ }^{1}$, A I Martín ${ }^{2}$ and \\ A López-Calderón ${ }^{\mathbf{1}}$ \\ ${ }^{1}$ Department Fisiología, Facultad de Medicina, Universidad Complutense, 28040 Madrid, Spain \\ ${ }^{2}$ Department CC Morfológicas y Fisiología, Universidad Europea, 28670 Madrid, Spain \\ (Requests for offprints should be addressed to A López-Calderón, Departamento de Fisiología, Facultad de Medicina, Universidad Complutense, \\ 28040 Madrid, Spain; Email: ALC@eucmax.sim.ucm.es)
}

\begin{abstract}
Adjuvant-induced arthritis in rats is associated with growth failure, hypermetabolism and accelerated protein breakdown. We have previously reported that adjuvant-induced arthritis in rats results in a decrease in body weight gain, pituitary GH mRNA, circulating GH and IGF-I together with an increase in serum IGF-binding proteins (IGFBPs). The aim of this study was to analyze the role of GH in the decrease in body weight and in the alterations in the IGF-I system observed in chronic inflammation.

Male Wistar rats were injected with complete Freund's adjuvant and 16 days later arthritic rats were injected daily with recombinant human $\mathrm{GH}(\mathrm{rhGH})(3 \mathrm{IU} / \mathrm{kg}$ s.c.) for 8 days; control rats received $250 \mu \mathrm{l}$ saline. Arthritis significantly decreased body weight gain and serum IGF-I. These decreases were not due to the reduced food intake, since in pair-fed rats they were not observed. Furthermore, administration of rhGH to arthritic rats increased body weight gain without modifying food intake. To
\end{abstract}

further investigate the effect of $\mathrm{GH}$ administration, 14 days after adjuvant injection both control and arthritic rats were treated with $0,1 \cdot 5,3$ or $6 \mathrm{IU} / \mathrm{kg}$ of $\mathrm{rhGH}$. GH treatment at the dose of 3 and $6 \mathrm{IU} / \mathrm{kg}$ significantly increased body weight gain in arthritic rats. GH administration, at the higher dose of $6 \mathrm{IU} / \mathrm{kg}$, increased hepatic and serum concentrations of IGF-I in both control and arthritic rats. In control rats, rhGH at the three doses assayed increased circulating IGFBP-3. GH treatment in arthritic rats decreased IGFBP-1 and -2 , and did not modify IGFBP-4. $\mathrm{GH}$ treatment at the dose of $3 \mathrm{IU} / \mathrm{kg}$ also decreased circulating IGFBP-3 in arthritic rats.

These data suggest that $\mathrm{GH}$ treatment can ameliorate the catabolism observed in adjuvant-induced arthritis, an effect mediated, at least in part, by modifications in the circulating IGFBPs.

Journal of Endocrinology (2000) 165, 537-544

\section{Introduction}

Adjuvant-induced arthritis in rats, a chronic inflammatory illness, is associated with a decrease in body weight and cachexia (Roubenoff et al. 1997). As described in other catabolic diseases, an increase in the levels of circulating glucocorticoids and a decrease in food intake have been observed in arthritic rats (Harbuz \& Lightman 1992, Roubenoff et al. 1997). Those effects seem to be secondary to the activation of the inflammatory response, since endotoxin administration in rodents induced similar responses, a reduction in body weight with an activation of the hypothalamic-pituitary-adrenal axis (Peisen et al. 1995).

Adjuvant-induced arthritis not only activates the adrenal axis, but also modifies other hormones from the somatotropic axis. A decrease in serum growth hormone $(\mathrm{GH})$ and pituitary $\mathrm{GH}$ mRNA has been described during the early phase before and after the disease develops
(Neidhart \& Flückiger 1992, Selgas et al. 1997). We have recently reported that the decrease in GH mRNA is concomitant with a decrease in serum and hepatic insulinlike growth factor-I (IGF-I) that correlates with the decrease in body weight in arthritic rats (López-Calderón et al. 1999).

The inflammatory cytokines tumor necrosis factor (TNF) and interleukin-1 are able to inhibit pituitary GH secretion (Bernton et al. 1987, Walton \& Cronm 1989, Peisen et al. 1995), and they have also been shown to inhibit hepatic IGF-I synthesis both in vivo and in vitro (Fan et al. 1995, Thissen \& Verniers 1997). Thus, the decrease in IGF-I serum concentration in arthritic rats could be secondary to alterations in pituitary GH or be due to an inhibitory effect of cytokines at the hepatic level.

The decrease in GH secretion and in circulating IGF-I levels during chronic inflammation is associated with high levels of IGF-binding sites in serum (Soto et al. 1998, López-Calderón et al. 1999). As serum IGF-binding 
proteins (IGFBPs) in certain situations can be growth inhibitors (Rechler \& Clemmons 1998), the alterations in circulating IGFBPs can play an important role in the decrease in body weight observed in chronic inflammation. In humans, growth retardation is a serious problem in juvenile chronic arthritis (JCA). Low levels of IGF-I have been repeatedly reported in JCA and in rheumatoid arthritis (Davies et al. 1994, Foppiani et al. 1998). Normal and reduced GH secretion have been observed in rheumatoid arthritis (Butenandt et al. 1974, Woo 1994). Nevertheless, recombinant human GH (rhGH) administration to children with JCA partially counteracts the adverse effects of this disease on growth and metabolism (Davies et al. 1994, Touati et al. 1998). GH and IGF-I are essential hormones in stimulating protein synthesis and body weight, and abnormalities in the IGF-I and IGFBPs have been associated with catabolic states (Bentham et al. 1993). These data indicate that the wasting syndrome observed in adjuvant-induced arthritis (Roubenoff et al. 1997) can be, in part, secondary to the alterations in GH, IGF-I and IGFBPs. The aim of this work was to analyze if rhGH administration to arthritic rats was able to reverse the effect of this disease on body weight and on IGF-I and IGFBPs. The results suggest that $\mathrm{rhGH}$, although it does not improve the inflammatory illness, can prevent the alterations in body weight and IGF-I and IGFBPs induced by chronic arthritis.

\section{Material and Methods}

Male Wistar rats were purchased from Charles River (Barcelona, Spain). Animals were maintained under controlled temperature $\left(20-22{ }^{\circ} \mathrm{C}\right)$ and light conditions (lights on from 0730 to $1930 \mathrm{~h}$ ), and housed three or four per cage. Food and water were freely available. The experimental procedures followed the guidelines recommended by the European Union for the care and use of laboratory animals.

In the first experiment, the effect of experimental arthritis on food intake was examined. Arthritis was induced in rats by an i.d. injection of complete Freund's adjuvant (1 mg heat-inactivated Mycobacterium butyricum; Difco Laboratories, Detroit, Michigan, USA) at the base of the tail. Control animals were injected with vehicle (paraffin oil). We have previously observed that 14 days after adjuvant injection arthritic rats start to develop signs of inflammation. Therefore, at this time rats were divided into three groups: control, arthritic and pair-fed. Body weight, food intake and the arthritis index scores (see below) were examined daily. Food intake per cage was calculated by measuring the difference between the initial and the remaining amount of pellets in the feeder, and expressed as grams per rat per $100 \mathrm{~g}$ body weight. The same amount of food consumed by the arthritic rats was given to the pair-fed group the following day. Assessment of arthritis was performed by measuring the arthritis index of each animal, which was scored by grading each paw from 0 to 4 . Grading was determined as: 0 , no erythema or swelling; 1, slight erythema or swelling of one or more digits; 2, swelling of the entire paw; 3 , erythema and swelling of the ankle; 4, ankylosis, incapacity to bend the ankle. The severity score was the sum of the clinical scores of each limb, the maximum value being 16 (Tanaka et al. 1996). On day 22 after adjuvant injection rats were killed and blood was allowed to clot and was centrifuged and serum stored at $-20{ }^{\circ} \mathrm{C}$ until IGF-I and IGFBPs assays were performed.

In the second experiment, the effect of rhGH administration to arthritic rats was examined. On day 16 after the adjuvant injection, arthritic rats were divided into two groups, one received $3 \mathrm{IU} / \mathrm{kg}$ s.c. of $\mathrm{rhGH}$ (Saizen, Serono, Italy) and the second group was injected with $250 \mu \mathrm{l}$ saline. All rats were weighed daily from day 16 until day 23 after adjuvant injection. Arthritis index scores were also examined daily. On day 23 all animals were killed by decapitation and trunk blood was collected in tubes at $4{ }^{\circ} \mathrm{C}$. The blood was allowed to clot and was centrifuged and serum stored at $-20^{\circ} \mathrm{C}$ until IGF-I and IGFBPs assays were performed.

In a third set of experiments, we tested the effect of administering different doses of rhGH to arthritic and control rats. Both arthritic and control rats were divided into four groups that were treated with $0,1 \cdot 5,3$ or 6 IU/kg of rhGH s.c. daily at $0900 \mathrm{~h}$, from day 14 to 22 . Rats were injected, weighed and the arthritis index score examined daily. Animals were killed by decapitation between 1130 and $1230 \mathrm{~h}$ and trunk blood was collected in cooled tubes, allowed to clot and was centrifuged and serum stored at $-20{ }^{\circ} \mathrm{C}$ until IGF-I and IGFBPs analyses were performed. The liver was removed, dissected, frozen and stored at $-20^{\circ} \mathrm{C}$ until IGF-I assay.

Serum IGF-I concentrations were measured by a double-antibody RIA previously described (Soto et al. 1998). Hepatic IGF-I was extracted as described by Torres-Aleman et al. (1992). Samples were homogenized in $1 \mathrm{M}$ acetic acid, boiled for $20 \mathrm{~min}$, and lyophilized. Levels of IGF-I were expressed in terms of IGF-I A52-EPD-186 standard (Eli Lilly \& Company, Madrid, Spain) The intra-assay coefficient of variation was $8 \%$. Samples from one experiment were run in the same assay.

Protein content was measured by Bradford's method (1976).

\section{Western ligand blot of IGFBPS}

Western blots were prepared as previously described (Hossenlop et al. 1986). Two microliters of sera were diluted in sample buffer and boiled for $2 \mathrm{~min}$ at $100{ }^{\circ} \mathrm{C}$, and submitted to electrophoresis on 1\% SDS-12.5\% acrylamide gels under non-reducing conditions. Following electrophoresis, proteins were transferred onto 
nitrocellulose sheets (Hybond-C extra, Amersham International, Amersham, Bucks, UK). After transfer the nitrocellulose sheets were dried and blocked for $1 \mathrm{~h}$ with 5\% non-fat dry milk, $0 \cdot 1 \%$ Tween (Sigma, Madrid, Spain), in Tris-buffered saline. The nitrocellulose membranes were incubated overnight at $4{ }^{\circ} \mathrm{C}$ with ${ }^{125}$ I-labeled IGF-I $\left(5 \times 10^{5}\right.$ c.p.m. $\left./ \mathrm{ml}\right)$, and blots were exposed at $-80{ }^{\circ} \mathrm{C}$ to X-ray film (Kodak X-Omat AR, Eastman Kodak, Rochester, NY, USA). Autoradiographs were analyzed by densitometric scanning using a PC-Image (Foster Findlay Associates Ltd, Newcastle, UK) VGA24 program for Windows. To obtain semiquantitative data for statistical analysis, each gel was run with six serum samples from each experimental group and three with a pool of control samples. The density of the IGFBP bands in each lane was expressed as the percentage of the mean density of control sera.

\section{Statistical analysis}

All data are presented as the mean \pm s.E.M. Comparisons between means were made by one-way or two-way ANOVA and subsequent Duncan's multiple range test. Comparisons between two groups were performed using Student's $t$-test. Simple linear regression was used to determine dose-related responses to treatment with different GH doses. Significance was assumed at $P<0 \cdot 05$.

\section{Results}

\section{Experiment 1}

Arthritic rats consumed 10\% less food than control rats $(P<0 \cdot 01)$. As seen in Fig. 1 , the daily body weight gain in arthritic rats was significantly lower than that observed in the control group throughout the entire experiment $(P<0 \cdot 01)$. This decrease does not only seem to be due to the decrease in food intake, since body weight gain in the pair-fed rats only decreased during the first 2 days of food restriction. Twenty-two days after adjuvant injection, serum concentrations of IGF-I were significantly lower in arthritic than in the control animals (1095 \pm 55 vs $1287 \pm 45 \mathrm{ng} / \mathrm{ml}, P<0 \cdot 05)$. However, pair-fed rats had similar serum IGF-I concentrations to control rats $(1323 \pm 60 \mathrm{ng} / \mathrm{ml})$.

\section{Experiment 2}

On day 16 after adjuvant injection, before $\mathrm{GH}$ administration started, the mean body weight was lower in arthritic than in control rats $(171 \pm 6 \cdot 2$ vs $236 \pm 3 \cdot 8 \mathrm{~g}$, $P<0 \cdot 01)$. During the 8 days of the experiment, arthritic rats injected with saline gained less body weight than controls, and this decrease in body weight gain was concomitant with a significant $(P<0 \cdot 01)$ decrease in food

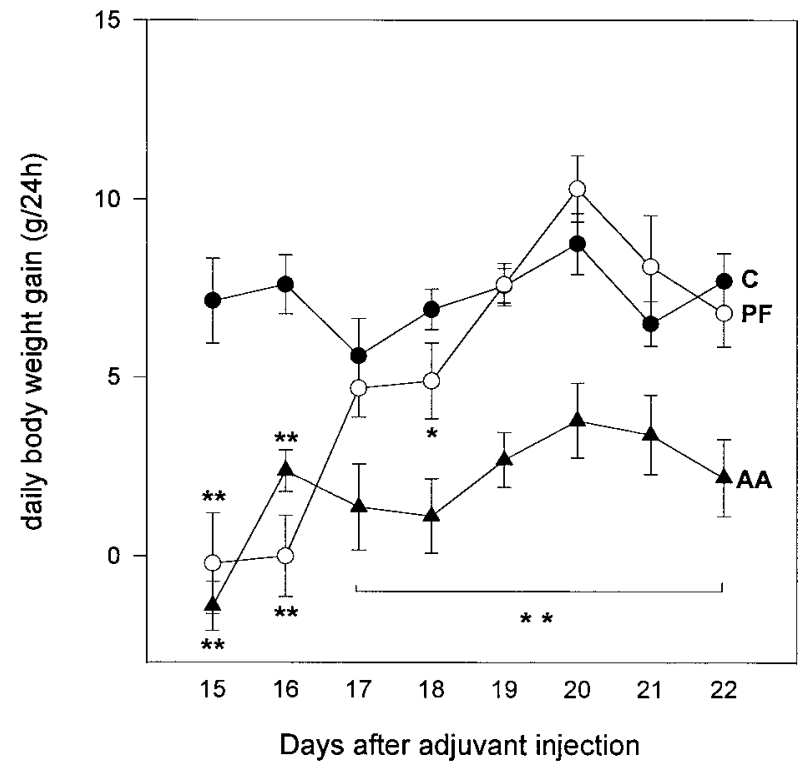

Figure 1 Daily body weight gain in arthritic (AA), control (C) and pair-fed (PF) rats. Values are means \pm S.E.M. for at least nine rats per group. ${ }^{*} P<0 \cdot 05,{ }^{* *} P<0 \cdot 01$ vs control; Duncan's multiple range test.

intake (Fig. 2). GH administration to arthritic rats induced an increase in body weight gain, higher than in the arthritic rats injected with saline $(\mathrm{F} 1,88=38, P<0 \cdot 01)$. The stimulatory effect of GH treatment on body weight was not due to an increase in food intake, since over the 8 days of treatment food intake was similar in both groups of arthritic rats, independent of GH treatment (Fig. 2). GH administration to arthritic rats did not modify the splenomegaly or the arthritis index score observed in the arthritic rats injected with saline (Table 1).

Arthritis decreased serum concentrations of IGF-I, and $\mathrm{GH}$ treatment was not able to increase serum concentrations of IGF-I in arthritic rats (data not shown). There

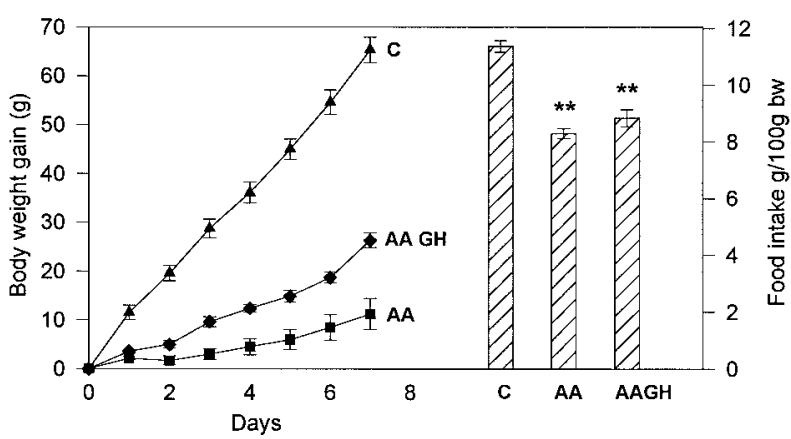

Figure 2 Effect of adjuvant-induced arthritis and administration of $\mathrm{rhGH}(3 \mathrm{IU} / \mathrm{kg})$ on body weight gain and mean food intake per rat. $\mathrm{AA}=$ arthritic rats injected with saline, $\mathrm{AA} \mathrm{GH}=$ arthritic rats receiving $\mathrm{GH}, \mathrm{C}=$ controls injected with saline. Values are means \pm S.E.M. for at least seven rats per group. ${ }^{*} P<0 \cdot 01 \mathrm{vs}$ control; Duncan's multiple range test. 
Table 1 Effect of $\mathrm{GH}$ administration to arthritic rats on relative splenic weight and arthritis index scores. Data are expressed as the mean \pm S.E.M.

\begin{tabular}{|c|c|c|c|c|}
\hline & $n$ & Treatment & $\begin{array}{l}\text { Spleen } \\
(\mathrm{mg} / 100 \mathrm{~g})\end{array}$ & $\begin{array}{l}\text { Arthritis } \\
\text { scores }\end{array}$ \\
\hline Control & 10 & - & $323 \pm 12$ & - \\
\hline Arthritic & 7 & Saline & $667 \pm 23^{* *}$ & $11 \pm 0 \cdot 7$ \\
\hline Arthritic & 7 & $\mathrm{GH}$ & $617 \pm 28^{* *}$ & $11 \pm 0 \cdot 6$ \\
\hline
\end{tabular}

${ }^{*} P<0 \cdot 05,{ }^{* *} P<0 \cdot 01$ compared with control. One-way ANOVA followed by the Duncan test.

was no difference in serum concentrations of glucose between arthritic rats injected with GH or saline (120 \pm $2 \cdot 0$ vs $115 \pm 5 \cdot 2 \mathrm{mg} / \mathrm{dl})$.

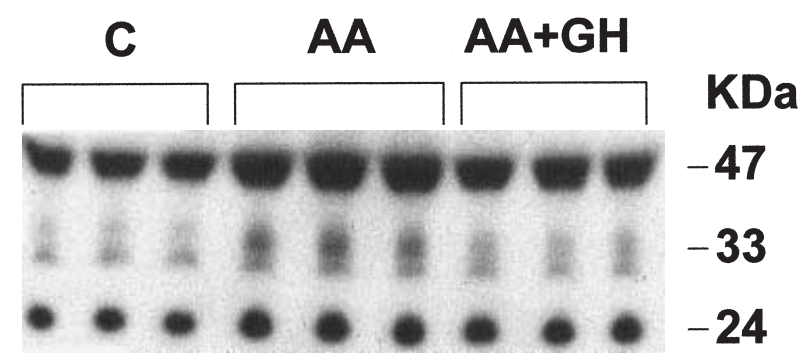

Figure 3 Representative Western ligand blot of IGFBPs in $2 \mu$ l serum from control rats injected with saline $(C)$ or arthritic rats injected with saline (AA) or with rhGH $(A A+G H)$. IGFPBs were separated by SDS-PAGE on a $12.5 \%$ gel, transferred to nitrocellulose, ligand blotted with ${ }^{125}$ I-IGF-I and visualized via autoradiography; approximate molecular masses of each band are indicated on the right. The 47, 33 and $24 \mathrm{kDa}$ IGFBPs represent IGFBP-3, IGFBP-1 and -2 and IGFBP-4 respectively.

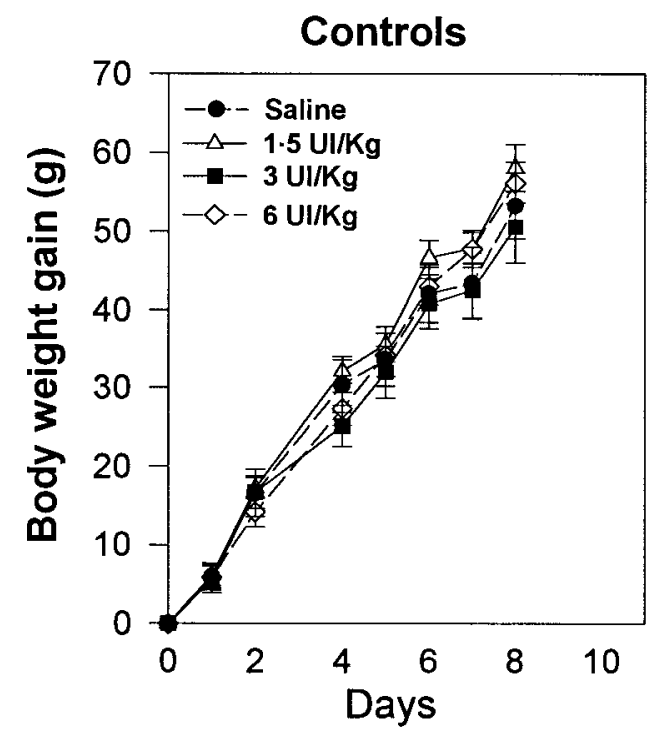

Western ligand blot analysis of rat serum IGFBPs (Fig. 3) showed the characteristic pattern with a band of an apparent molecular mass of $47 \mathrm{kDa}$ identified as IGFBP-3, a group of two bands of $33 \mathrm{kDa}$ (IGFBP-1 and -2) and a $24 \mathrm{kDa}$ band (probably IGFBP-4). As shown in Fig. 3, arthritis increased the serum IGFBPs of 47,33 and $24 \mathrm{kDa}$ $(P<0 \cdot 01)$, and $\mathrm{GH}$ administration to arthritic rats reversed the increase in 47 and $33 \mathrm{kDa}$ IGFBPs, whereas the arthritis-induced increase in $24 \mathrm{kDa}$ IGFBP was only partially reversed by $\mathrm{GH}$ administration.

\section{Experiment 3}

When administered to control rats, rhGH had no effect on body weight gain (Fig. 4). In contrast, in arthritic rats, rhGH treatment increased body weight gain at the doses of $3 \mathrm{IU} / \mathrm{kg}(\mathrm{F} 1,120=16, P<0 \cdot 01)$ and $6 \mathrm{IU} / \mathrm{kg}$ $(\mathrm{F} 1,113=13, P<0 \cdot 01)$. As described in the result of the first experiment, $\mathrm{GH}$ administration to arthritic rats, at the three doses studied, did not modify the splenic weight or the arthritis scores (data not shown).

As seen in Fig. 5, the stimulatory effect of GH on serum IGF-I in control rats was dose related $(\mathrm{F} 1,34=8 \cdot 4$, $P<0 \cdot 01)$, the increase being statistically significant in the rats that received 3 or $6 \mathrm{IU} / \mathrm{kg}$ of $\mathrm{GH}$. In the arthritic rats, $\mathrm{rhGH}$ administration also induced an increase in serum concentrations of IGF-I in a dose-dependent manner $(\mathrm{F} 1,32=4 \cdot 9, P<0 \cdot 05)$, but the increase was only significant in the group that received $6 \mathrm{IU} / \mathrm{kg}$ of $\mathrm{rhGH}$ (Fig. 5). A dose-dependent increase in hepatic concentrations of IGF-I was observed in the rats injected with rhGH whether arthritic $(\mathrm{F} 1,32=5 \cdot 4, P<0 \cdot 05)$ or not $(\mathrm{F} 1,34=$ $7 \cdot 79, P<0.01)$. In both control and arthritic rats, the

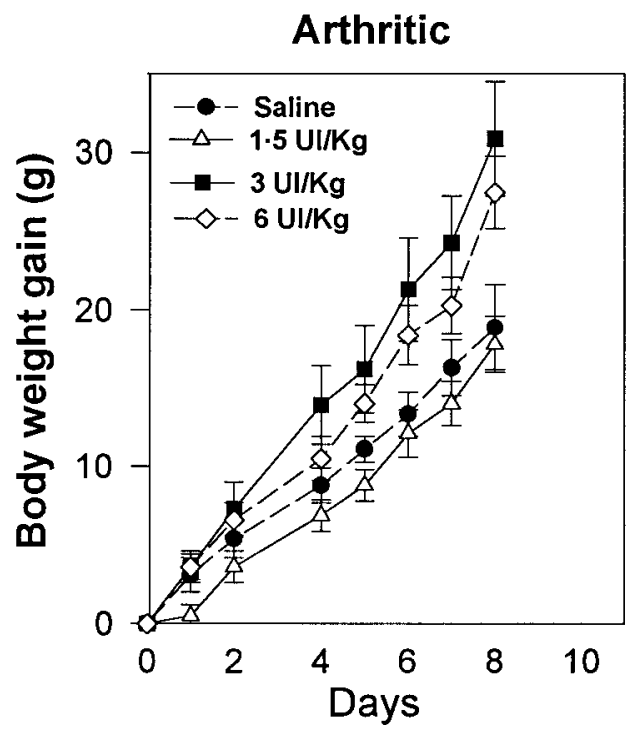

Figure 4 Effect of rhGH treatment at different doses over 8 days on body weight gain in control and arthritic rats. Values are means \pm S.E.M. for at least eight rats per group. 


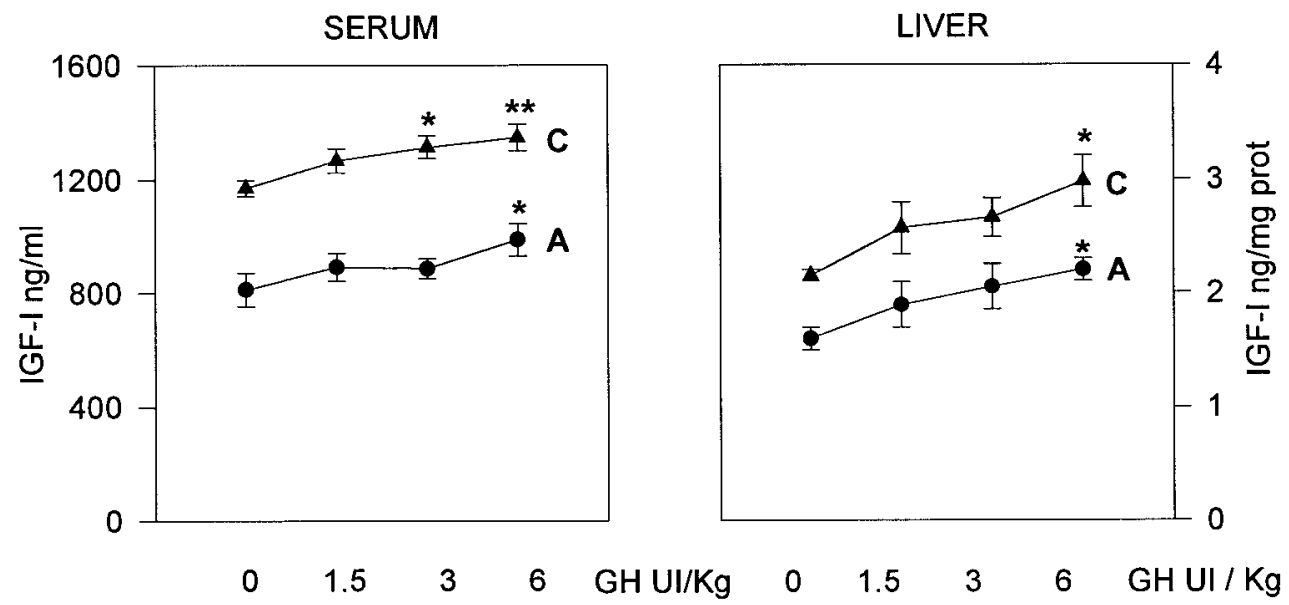

Figure 5 Changes in serum and hepatic concentrations of IGF-I in control (C) and arthritic rats (A) after administration of varying rhGH doses. Values are means \pm S.E.M. for at least seven rats per group. Two-way ANOVA revealed that arthritis decreases $\left(F_{1,66}=112, P<0 \cdot 01\right)$ and $\mathrm{GH}$ administration increases $\left(F_{1,66}=3 \cdot 22\right.$, $P<0.05)$ serum concentrations of IGF-I. Hepatic concentrations of IGF-I were also decreased by arthritis $\left(F_{1,64}=21, P<0 \cdot 01\right)$ and increased by $G H$ treatment $\left(F_{1,64}=4 \cdot 4, P<0 \cdot 01\right) .{ }^{*} P<0 \cdot 05,{ }^{* *} P<0 \cdot 01$ vs respective group injected with saline; Duncan's multiple comparison test.

increase in hepatic concentrations of IGF-I was significant in the groups injected with $6 \mathrm{IU} / \mathrm{kg}$ of $\mathrm{rhGH}$ (Fig. 5).

Figure 6 illustrates the effect of rhGH administration to control rats on serum concentrations of IGFBPs. GH increased the serum concentrations of IGFBP-3 in the control rats that received $1.5,3$, or $6 \mathrm{IU} / \mathrm{kg}$, whereas IGFBP-1 and -2 and the $24 \mathrm{kDa}$ IGFBP were not modified by any of the GH doses used in the study (Fig. 6). Arthritis increased serum concentrations of IGFBP-3 (119 \pm 5 vs $97 \pm 6, t=2 \cdot 87, P<0 \cdot 01)$, IGFBP-1 and $-2 \quad(142 \pm 7$ vs $99 \pm 7, \quad t=4 \cdot 29, \quad P<0 \cdot 01)$, and IGFBP-4 (114 \pm 2 vs $99 \pm 4, t=3 \cdot 4, P<0 \cdot 01)$. GH treatment reverted the effect of arthritis on IGFBP-3 in the rats that received $3 \mathrm{IU} / \mathrm{kg}$. Serum concentrations of IGFBP-1 and -2 were also decreased by $\mathrm{GH}$ administration in all the doses analyzed. GH administration did not modify IGFBP-4 in the arthritic rats (Fig. 7).

\section{Discussion}

As we have recently reported, arthritic rats showed a decrease in body weight and in circulating IGF-I levels, which appears to be inversely related to the increase in serum binding activity of the IGFBPs (López-Calderón et al. 1999). The results of this study demonstrate that the decrease in serum concentrations of IGF-I in adjuvantinduced arthritis cannot be secondary to the anorexia, since pair-fed rats had no modifications in circulating IGF-I. Those effects could be related to the inflammatory response since similar modifications were observed in rats chronically injected with endotoxin (Soto et al. 1998).
These data are in accordance with those observed in patients with rheumatoid arthritis who have an increased resting energy expenditure and increased protein breakdown (Roubenoff et al. 1994). Also, an association between the activity of the inflammatory cytokine TNF- $\alpha$ and weight loss in arthritic rats was found (Roubenoff et al. 1997).

Our data show that the arthritis-induced decrease in body weight gain can be, in part, prevented by $\mathrm{GH}$ treatment. The stimulatory effect of rhGH on body weight gain in arthritic rats is not due to an increase in food intake. Similarly, in hypophysectomized rats, GH administration produced dose-dependent increases in body weight, without increasing food intake (Clark et al. 1985). An increased efficiency of food conversion in rhGH-treated rats could account for the effect of $\mathrm{GH}$ on body weight in the arthritic rat. This effect could be due to an increase in IGF-I synthesis or to a metabolic effect of GH by itself.

Although GH administration did not reverse the arthritis-induced decrease in serum IGF-I, it stimulated serum and hepatic IGF-I in the arthritic rats as in the controls, at the dose of $6 \mathrm{IU} / \mathrm{kg}$. The dose-dependent increase in hepatic and serum IGF-I with rhGH administration indicates that in arthritic rats the liver is able to respond to GH by synthesizing this hormone. Thus, the decrease in GH secretion observed in the arthritic rat could be responsible for the decrease in circulating IGF-I and body weight gain. Nevertheless, we cannot exclude other causes in the decrease in circulating IGF-I in chronic inflammation. GH resistance has been described during the inflammatory response in rats (Defalque et al. 1999). However, GH administration in septic rats increases visceral protein content (Okamura et al. 1989), and in 


\section{Controls}

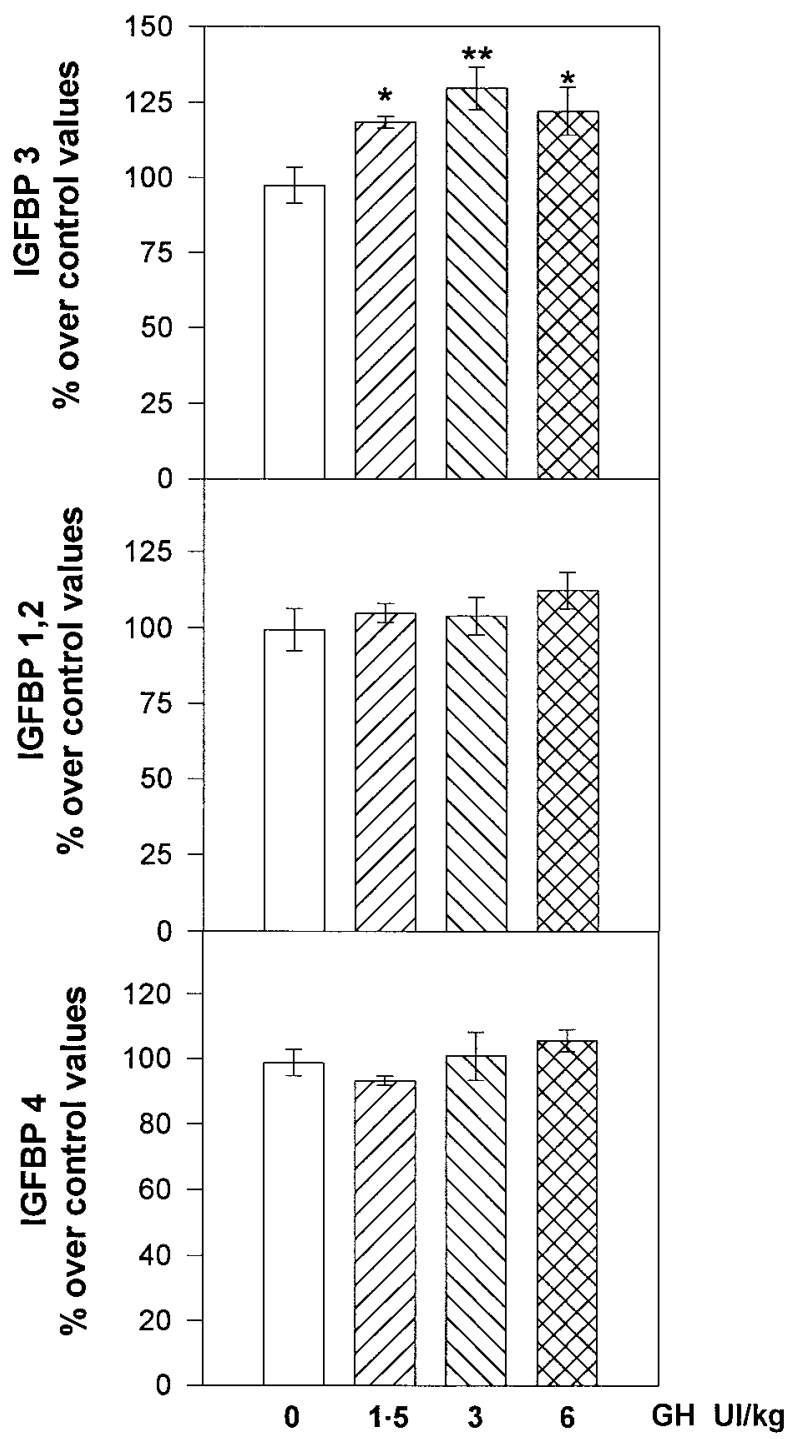

Figure 6 The effect of different doses of rhGH administered over 8 days on serum IGFBPs in control rats. Data from six individual rats were quantified by densitometry and expressed as percentage of the mean value in control rats treated with saline. ${ }^{*} P<0 \cdot 05$, ${ }^{*} P<0 \cdot 01$ vs control group injected with saline (open bars); Duncan's multiple comparison test.

septic patients GH ameliorates the catabolic state by increasing protein synthesis and IGF-I levels (Voerman et al. 1992). In addition, rhGH administration to children with rheumatoid arthritis increases height velocity and plasma levels of IGF-I (Davies et al. 1997).

High doses of GH in patients with critical illnesses have been associated with increased mortality (Takala et al. 1999). Similar data have been reported in rats after acute endotoxin administration (Liao et al. 1997). Although both

\section{Arthritics}

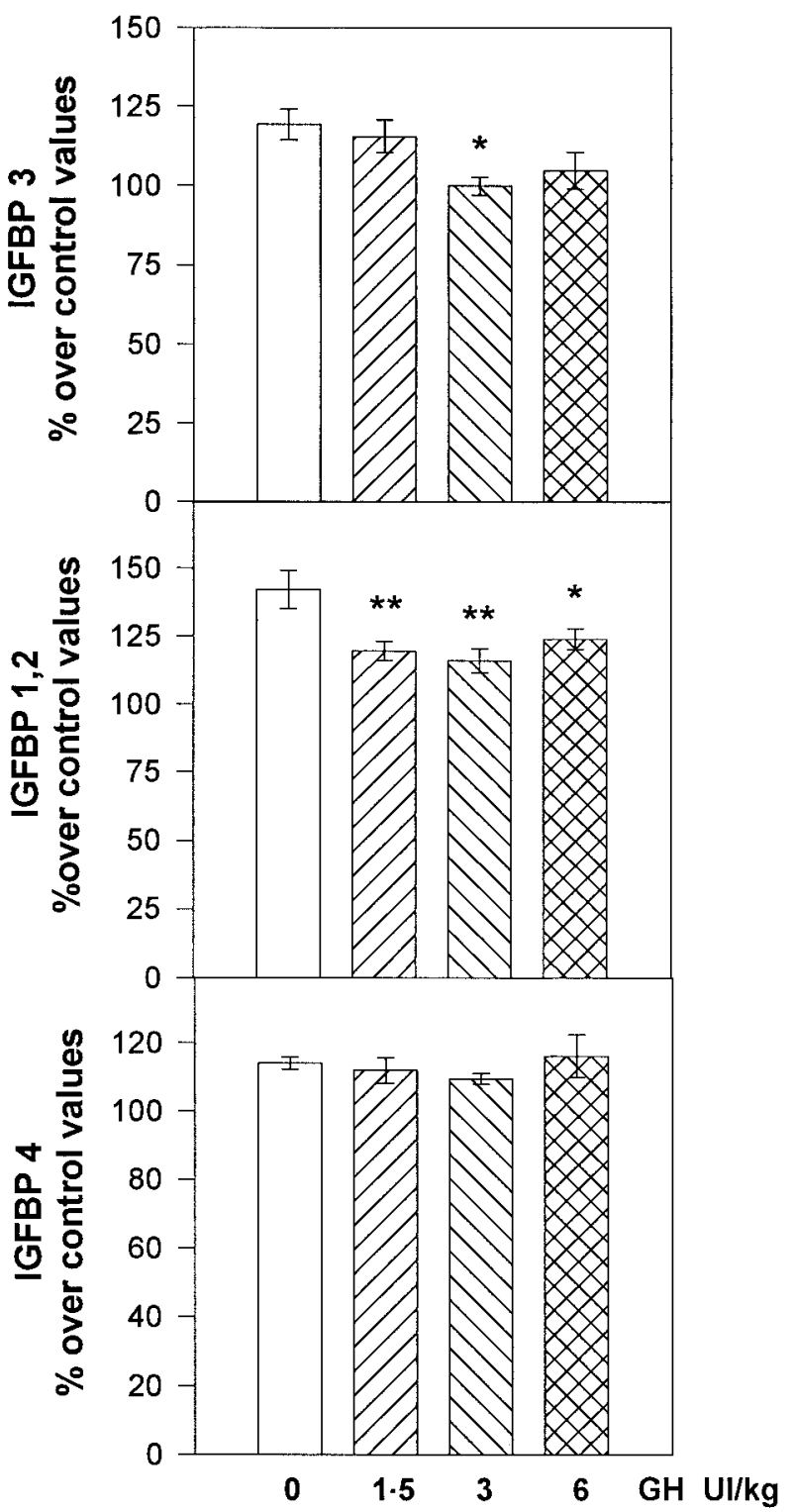

Figure 7 The effect of different doses of rhGH administered over 8 days on serum IGFBPs in adjuvant-induced arthritic rats. Data from six individual rats were quantified by densitometry and expressed as percentage of the mean value in control rats treated with saline. ${ }^{*} P<0 \cdot 05,{ }^{*} P<0 \cdot 01$ vs arthritic group injected with saline (open bars); Duncan's multiple comparison test.

acute lipopolysaccharide (LPS)- and adjuvant-induced arthritis stimulate the inflammatory response, the endocrine responses are not the same. Acute LPS administration induces hypoglycemia (Soto et al. 1998) and this effect is exacerbated by GH administration (Liao et al. 1997). However, chronic LPS administration (Soto et al. 1998) 
and adjuvant-induced arthritis (López-Calderón et al. 1999) are not associated with hypoglycemia. Furthermore, both chronic LPS- and adjuvant-induced arthritis increased all the IGFBPs, whereas acute LPS injection only increased the $33 \mathrm{kDa}$ IGFBP (Soto et al. 1998).

The fact that the dose of $3 \mathrm{IU} / \mathrm{kg}$ stimulates body weight gain without increasing serum concentrations of IGF-I, suggests that the effect of rhGH on body weight is not only mediated by IGF-I. Other studies indicate that GH is more potent than IGF-I administration in promoting growth (Fielder et al. 1996). In the arthritic rats, the decrease in GH, IGF-I and body weight gain is associated with an increase in the IGFBPs. These data indicate that the bioavailability of IGF-I is further reduced in these rats. Disregulation in IGFBP-3 and other IGFBPs appears to be involved in arthritic disorders (Martel-Pelletier et al. 1998). Whereas it is accepted that IGFBP-1 and -2 production may contribute to impaired metabolism in clinical conditions where cytokines production is increased (Fan et al. 1995, Benbassat et al. 1999), the role of IGFBP-3 is less known. IGFBP-3 is elevated in rats in a different catabolic situation as acute renal failure (Bohé et al. 1998). Furthermore, children with chronic renal failure are often growth retarded despite normal serum levels of GH and IGF, and recent studies suggest that the excess IGFBPs in serum may contribute to growth failure (Powell et al. 1998). The increase in IGFBP-3 in arthritic rats can be secondary to the increased cytokines release in this disease, since TNF- $\alpha$ and interferon- $\gamma$ have been shown to increase IGFBP-3 production (Katz et al. 1995, Rozen et al. 1998).

In contrast to that observed in serum IGF-I, all administered doses of rhGH normalize serum concentrations of the $33 \mathrm{kDa}$ band IGFBP corresponding to IGFBP-1 and -2 . Taking into account that $\mathrm{GH}$ is one of the regulators of IGFBP-1/2, these data can be due to the correction of the GH deficiency in the arthritic rats treated with rhGH. Similarly, hepatic IGFBP-1 synthesis is enhanced in hypophysectomized rats and down-regulated by $\mathrm{GH}$ administration (Seneviratne et al. 1990). The fact that rhGH decreases IGFBP-3 in arthritic rats is unexpected, since $\mathrm{GH}$ has been shown to increase serum concentration of IGFBP-3. It is unlikely that in our study GH treatment was not efficacious, since rhGH in control rats increases serum concentration of IGFBP-3 at all doses used in our study. In contrast, in arthritic rats, rhGH at the dose of $3 \mathrm{IU} / \mathrm{kg}$ decreases serum IGFBP-3, and this decrease is concomitant with an increase in body weight gain. Similarly, GH administration to JCA children improved growth velocity and increased the IGF-I/IGFBP-3 ratio (Touati et al. 1998).

There is evidence that free IGFBP-3 can inhibit cell growth in vitro, and this inhibitory effect can be attenuated by IGF-I (Oh 1997). Furthermore, the antiproliferative action of antiestrogens is correlated with suppression of circulating IGF-I and upregulation of IGFBP-3 (for review see Rosen \& Pollak 1999). All these data indicate that IGFBP-3 is an important regulator of cell growth, and inhibits it through mechanisms both dependent on and independent of IGF-I binding. The ability of rhGH to improve body weight gain in arthritic rats and its correlation with circulating IGFBP-3 suggest an important role of this IGFBP in the catabolic response induced by chronic inflammation.

\section{Acknowledgements}

The authors are indebted to A Carmona for technical assistance and to Christina Bickart for correction of the manuscript. We are grateful to Lilly Spain for the IGF-I, and to the US National Institute of Diabetes, Digestive and Kidney Diseases National Hormone and Pituitary Program for the antibody for IGF-I determinations. This work was supported by grants from Dirección General de Investigación Científica y Técnica (DGICYT PM 95-0068) and Fondo de Investigaciones Sanitarias de la Seguridad Social (Fis00-0949) and a fellowship to I Ibañez de Cáceres (BEFI, 99/9020).

\section{References}

Benbassat CA, Lazarus DD, Cichy SB, Evans TM, Moldawer LL, Lowry SF \& Unterman TG 1999 Interleukin-1 alpha (IL-1 alpha) and tumor necrosis factor alpha (TNF alpha) regulate insulin-like growth factor binding protein-1 (IGFBP-1) levels and mRNA abundance in vivo and in vitro. Hormone and Metabolic Research 31 209-215.

Bentham J, Rodriguez-Arnao J \& Ross RJM 1993 Acquired growth hormone resistance in patients with hypercatabolism. Hormone Research 40 87-91.

Bernton ED, Beach JE, Holaday JW, Smallridge RC \& Fein HC 1987 Release of multiple hormones by a direct action of interleukin on pituitary cells. Science 238 519-521.

Bohé J, Ding H, Qing DP, Yoon K, Hirschberg R, Wolgang GHI \& Kopple JD 1998 IGF-I binding proteins, IGF-I binding protein mRNA and IGF-I receptor mRNA in rats with acute renal failure given IGF-I. Kidney International 54 1070-1082.

Bradford MM 1976 A rapid and sensitive method for the quantification of microgram quantities of proteins utilizing the principle of proteindye binding. Analytical Biochemistry 72 248-254.

Butenandt O, Kelch A \& Rajman E 1974 Growth hormone studies in patients with rheumatoid arthritis with or without glucocorticosteroid therapy. European Journal of Pediatry 118 53-62.

Clark RG, Jansson J-O, Isaksson O \& Robinson ICAF 1985 Intravenous growth hormone: growth responses to patterned infusions in hypophysectomized rats. Journal of Endocrinology 104 53-61.

Davies UM, Rooney M, Preece MA, Ansell BM \& Woo P 1994 Treatment of growth retardation in juvenile chronic arthritis with recombinant human growth hormone. Journal of Rheumatology 21 153-158.

Davies UM, Jones J, Reeve J, Camacho-Hubner C, Charlett A, Ansell BM, Preece MA \& Woo PMM 1997 Juvenile rheumatoid arthritis. Effects of disease activity and recombinant human growth hormone on insulin-like growth factor I, insulin-like growth factor binding proteins 1 and 3, and osteocalcin. Arthritis and Rheumatism 40 332-340. 
Defalque D, Brandt N, Ketelslegers J-M \& Thissen J-P 1999 GH insensitivity induced by endotoxin injection is associated with decreased liver receptors. American Journal of Physiology 276 E565-E572.

Fan J, Char D, Bagby GJ, Gelato MC \& Lang CH 1995 Regulation of insulin-like growth factor-I (IGF-I) and IGF-binding proteins by tumor necrosis factor. American Journal of Physiology 269 1204-1212.

Fielder PJ, Mortensen DL, Mallet P, Carlsson B, Baxter RC \& Clark RG 1996 Differential long-term effects of insulin-like growth factor-I (IGF-I), growth hormone (GH), and IGF-I plus GH on body growth and IGF binding proteins in hypophysectomized rats. Endocrinology 137 1913-1920.

Foppiani L, Cutolo M, Sessarego P, Sulli A, Prete C, Seriolo B \& Giusti M 1998 Desmopressin and low-dose ACTH test in rheumatoid arthritis. European Journal of Endocrinology 138 294-301.

Harbuz MS \& Lightman SL 1992 Stress and hypothalamic-pituitaryadrenal axis: acute, chronic and immunological activation. Journal of Endocrinology 134 327-339.

Hossenlop P, Seurin D, Segovia-Quinson B, Hardouin S \& Binoux M 1986 Analysis of serum insulin-like growth factor binding protein using Western blotting: use of the method for titration of the binding proteins and competitive binding studies. Analytical Biochemistry 154 138-143.

Katz J, Weiss, Goldman B, Kanety H, Stannard B, LeRoith D \& Shemer J 1995 Cytokines and growth factors modulate cell growth and insulin-like growth factor binding protein secretion by the human salivary cell line. Journal of Cellular Physiology 165 223-237.

Liao W, Rudling M \& Angelin B 1997 Contrasting effects of growth hormone and insulin-like growth factor I on the biological activities of endotoxin in the rat. Endocrinology 138 289-295.

López-Calderón A, Soto L \& Martín AI 1999 Chronic inflammation inhibits $\mathrm{GH}$ secretion and alters the serum insulin-like growth factor system in rats. Life Sciences 65 2049-2060.

Martel-Pelletier J, Di-Battista JA, Lajeunesse D \& Pelletier JP 1998 IGF/IGFBP axis in cartilage and bone in osteoarthritis pathogenesis. Inflammation Research 47 90-100.

Neidhart M \& Flückiger EW 1992 Hyperprolactinaemia in hypophysectomized or intact male rats and the development of adjuvant arthritis. Immunology 77 449-455.

Oh Y 1997 IGFBPs and neoplasic models. Endocrine 7 111-113.

Okamura K, Okuma T, Tabira Y \& Miyaughi Y 1989 Effect of administered human growth hormone on protein metabolism in septic rats. Journal of Parenteral and Enteral Nutrition 13 450-454.

Peisen JN, McDonnell KJ, Mulroney SE \& Lumpkin MD 1995 Endotoxin-induced suppression of the somatotropic axis is mediated by interleukin- $1 \beta$ and corticotropin-releasing factor in the juvenile rats. Endocrinology 136 3378-3390.

Powell DR, Durham SK, Liu F, Baker BK, Lee PDK, Watkins SL, Campbell PG, Brewer ED, Hintz RL \& Hogg RJ 1998 The insulinlike growth factor axis and growth in children with chronic renal failure: a report of the Southwest Pediatric Nephrology Study Group. Journal of Clinical Endocrinology and Metabolism 83 1654-1661.

Rechler MM \& Clemmons DR 1998 Regulatory actions of insulinlike growth factor-binding proteins. Trends in Endocrinology and Metabolism 9 176-183.

Rosen CJ \& Pollak M 1999 Circulating IGF-I: new perspectives for a new century. Trends in Endocrinology and Metabolism 10 136-141.
Roubenoff R, Roubenoff RA, Cannon JG, Kehayias JJ, Zhuang H, Dawson-Hughes B, Dinarello CA \& Rosenberg IH 1994 Rheumatoid cachexia: cytokine-driven hypermetabolism and loss of lean body mass in chronic inflammation. Journal of Clinical Investigation 93 2379-2386.

Roubenoff R, Freeman LM, Smith DE, Abad LW, Dinarello CA \& Kehayias JJ 1997 Adjuvant arthritis as a model of inflammatory cachexia. Arthritis and Rheumatism 40 534-539.

Rozen F, Zhang J \& Pollak M 1998 Antiproliferative action of tumor necrosis factor-alpha on MCF-7 breast cancer cells is associated with increased insulin-like growth factor binding protein-3 accumulation. International Journal of Oncology 13 865-869.

Selgas L, Arce A, Esquifino AI \& Cardinali DP 1997 Twenty-fourhour rhythms of serum ACTH, prolactin, growth hormone, and thyroid-stimulating hormone, and of median-eminence norepinephrine, dopamine, and serotonin, in rats injected with Freund's adjuvant. Chronobiology International 14 253-265.

Seneviratne C, Luo J \& Murphy LJ 1990 Transcriptional regulation of insulin-like growth factor binding protein-1 expression by growth hormone. Molecular Endocrinology 4 1199-1204.

Soto L, Martín AI, Millán S, Vara E \& López-Calderón A 1998 Effects of endotoxin lipopolysaccharide administration on the somatotropic axis. Journal of Endocrinology 159 239-246.

Takala J, Ruokonen E, Webster NR, Nielsen MS, Zandstra DF, Vundelinckx G \& Hinds CJ 1999 Increased mortality associated with growth hormone treatment in critically ill adults. New England Journal of Medicine 341 785-792.

Tanaka H, Ueta Y, Yamashita U, Kannan H \& Yamashita H 1996 Biphasic changes in behavioral, endocrine, and sympathetic systems in adjuvant arthritis in Lewis rats. Brain Research Bulletin 39 33-37.

Thissen JP \& Verniers J 1997 Inhibition by interleukin-1 and tumor necrosis factor- $\alpha$ of the insulin-like growth factor I messenger ribonucleic acid response to growth hormone in rat hepatocyte culture. Endocrinology 138 1078-1084.

Torres-Aleman I, Pons S \& Santos-Benito FF 1992 Survival of Purkinje cells in cerebellar cultures is increased by insulin-growth factor I. European Journal of Neuroscience 4 864-869.

Touati G, Prieur AM, Ruiz JC, Noel M \& Czernichow P 1998 Beneficial effects of one-year growth hormone administration to children with juvenile chronic arthritis on chronic steroid therapy. I. Effects on growth velocity and body composition Journal of Clinical Endocrinology and Metabolism 83 403-409.

Voerman HJ, Strack RJM, Groeneveld ABJ, de Boer H, Nauta JP, Van der Veen EA \& Thijs LG 1992 Effects of recombinant human growth hormone in patients with severe sepsis Annals of Surgery 216 $648-655$.

Walton PE \& Cronm MJ 1989 Tumor necrosis factor- $\alpha$ inhibits growth hormone secretion from culture anterior pituitary cells. Endocrinology 125 925-929.

Woo PM 1994 Growth retardation and osteoporosis in juvenile chronic arthritis. Clinical and Experimental Rheumatology 12 (Suppl 10) $\mathrm{S} 87-\mathrm{S} 90$.

Received 6 October 1999

Revised manuscript received 29 December 1999

Accepted 27 January 2000 